\title{
William Blake and His Poem "London"
}

\author{
Changjuan Zhan \\ School of Foreign Languages, Qingdao University of Science and Technology, Qingdao, Shandong, China
}

\begin{abstract}
This paper gives a detailed introduction to William Blake, a versatile poet, dramatist, artist, engraver, and publisher; and the most original romantic poet as well as painter and printmaker of the $18^{\text {th }}$ century. Then his works are also introduced according to time order among which two of his collections of poems, i.e. "the songs of innocence" and "the songs of experiences" are given special attention. The features and comments on his works are introduced and demonstrated in his most famous poem "London", from "the songs of experiences". The paper analyzes the various technical features in this poem respectively-key image and three encounters around which the whole poem is centered; symbolism and capitalization which are used a lot in it; the choice and repetition of words which enhance the theme of the poem; and the rhyme and rhythm which give the poem a musical pattern. And then a conclusion is made that through these features, William Blake did achieve an overall impact which convey the horror and injustice that was London.
\end{abstract}

Index Terms -William Blake, London, technical features, image, capitalization, repetition, rhyme and rhythm

\section{AN INTRODUCTION TO WiLliAm BLAKE}

\section{A. William Blake's Life}

William Blake was a versatile poet, dramatist, artist, engraver, and publisher. He was the most independent and the most original romantic poet as well as painter and printmaker of the $18^{\text {th }}$ century. He was born in November 1757 in London. Among the seven children in his family, he was the third one. His father, James, an Irish man, ran a hosiery business. When he was only ten years old, he left school where he had learned reading and writing. Then his mother Catherine Wright Armitage Blake taught him at home. Blake was baptised at St James's Church, and Bible had a profound influence on Blake, and remained a source of inspiration throughout his life (http://en.wikipedia.org/wiki/William_Blake, May, 2013).

At home, his father bought him some Greek antiquities and he began engraving copies of drawings of them. In these drawings Blake had his first chance to get to know the classical forms through the work of Raphael, Michelangelo, Marten Heemskerk and Albrecht Dürer(http://en.wikipedia.org/wiki/William_Blake, May, 2013). He was sent to a drawing school at the age of ten. He studied his favorite subjects actively and it was in this period that Blake made his first explorations in poetry.

At 15, in the year 1772, William Blake became apprenticed to engraver James Basire of Great Queen Street, for the term of seven years. He was once sent by Basire to copy the Gothic churches in London. His experiences in Westminster Abbey helped him a lot in forming his own artistic style and his own ideas. At the age of 21, he ended his apprenticeship and he began graving on his own. He started being a professional engraver.

In 1779, he was enrolled as a student for six years at the school of the Royal Academy of Arts. Although the terms of his studying there were tuition free, he had to pay for all the daily expenses by himself for all the six years. In the school, he got to learn the styles of many famous and fashionable painters among whom Rubens' style was considered by him as unfinished and he rebelled against it. But the school's first president, Joshua Reynolds, championed his style. Over time, Blake came to detest Reynolds' attitude towards art, especially his pursuit of "general truth" and "general beauty". Reynolds wrote in his Discourses that the "disposition to abstractions, to generalizing and classification, is the great glory of the human mind"; Blake responded, in marginalia to his personal copy, that "To Generalize is to be an Idiot; To Particularize is the Alone Distinction of Merit". Blake also disliked Reynolds' apparent humility, which he held to be a form of hypocrisy. Against Reynolds' fashionable oil painting, Blake preferred the Classical precision of his early influences, Michelangelo and Raphael (http://en.wikipedia.org/wiki/William_Blake, May, 2013).

In 1782, when he was 24 he married Catherine Boucher, the daughter of a market gardener. William not only taught Catherine to read and write, but he also trained her as an engraver. It turned out that his wife was of great help to his career. She gave him invaluable assistant in his works and endless spiritual support in his misfortunes. She assisted with the printing and hand coloring of his poems. They worked together to publish the "songs of innocence" in a "DIY" way which is quite popular today, in which William engraved his poems and paintings on the bronze board and Catherine helped with coloring and binding. But their works didn't sell well and their efforts earned him neither money nor reputation because their works were not appreciated by many people at the time. Despite the poverty and hardships, they insisted on publishing their works on their own instead of signing contracts with any publishers. His works hadn't got the attention they deserved before he died.

B. William Blake's Works 


\section{General introduction to his works.}

Between his 12th and his 20th years he had written poems. These poems were printed around the year 1783 under the title of "Poetical Sketches", which was his first collection of poems. In 1784, after his father died, William Blake and his former fellow apprentice, James Parker opened a print shop, and they began to operate with the well-known publisher Joseph Johnson, among whose cooperators there are many big names and excellent artists like John Flaxman, Thomas Stothard and George Cumberland. He became friends with many of them during his first year at the Royal Academy. They shared radical views, with Stothard and Cumberland joining the Society for Constitutional Information. Along with William Wordsworth and William Godwin, Blake had great hopes for the French and American revolutions but despaired with the rise of Robespierre and the Reign of Terror in France. In 1784 Blake composed his unfinished manuscript An Island in the Moon (http://en.wikipedia.org/wiki/William_Blake, May, 2013).

After 1788 he published several collections of poems, "There Is No Natural Religion" and "All Religions Are one" were written by him in about 1788. He wrote poems and printed "The song of Experiences" in 1789 and then etched his earliest "Prophetic Books", "The Book of Thel". Blake illustrated Original Stories from Real Life (1788; 1791) by Mary Wollstonecraft. They seem to have shared some views on sexual equality and the institution of marriage. In 1793's Visions of the Daughters of Albion, Blake condemned the cruel absurdity of enforced chastity and marriage without love and defended the right of women to complete self-fulfillment. In 1780s and 1790s the influence of American Revolution and French Revolution spread to Europe, and the fight against colonialism and feudalism was also widespread in England. During the years 1788-1793 Blake blended a lot with the political radicals and the social reformers at that time. As early as 1789, Blake wrote "French Revolution" and Prophetic Book". In 1790, "The Marriage of Heaven and Hell". In 1793, Blake issued a "Prospectus, To the Public". In 1794, "The Songs of Innocence" was published again, together with "The Songs of Experience". In 1804, Blake started to etch both "Milton" and "Jerusalem". Blake's poetry has generally been divided into two groups:

(1)Lyrical poems: "Poetical Sketches"(1783); "The Songs of Innocence”(1789);"The Songs of Experience” (1794)

(2)Prophetic Books contain:“Tiriel”(1789);“The Book of Thel”(1789);"Milton"(1808);“Jerusalem"(1818);"The Ghost of Abel"'(1822).

\section{2. "The Songs of Innocence" and "The song of Experiences"}

"The Songs of Innocence" shows Blake's advance in his artistic achievement as a poet, though some poems are not serious and thought-provoking. The appeal seems to be chiefly to children, and most of the poems in the collection have a strange, simple beauty both in their themes and their language and verse form and rhythm. It is a volume of lovely poems, depicting a enjoyable and innocent world with its evils and sufferings. However, in "The little black boy" and "The chimney sweeper", we find racial discrimination and sufferings of the poor. On the whole, the poems in this collection are short and lyrical and are indeed "happy songs" in which one feels the existence of social; harmony or at least a child's feeling of "God's in his heaven, All's s right with the world." But there are exceptions, like "The Little Black Boy" and "The Chimney-Sweeper".

"The Songs of Experience" (1794) was a much mature work. It showed the sufferings of the miserable. It marked the poet's progress in his outlook on life. To him, experience had brought a fuller sense of the power of evil, and of the great misery and pain of the people's life. Its symbol changes from the lamb to the tiger. It is certainly about the most important volume of all Blake's poetry, because it is maturer work than either "Poetical Sketches".(1783) or "The Songs of Innocence"(1789) The poems are short and lyrical and still assume the childlike tongue and use simple language, but we could find poet's deeper and more penetrating observation of reality. There are a lot of poems in the "Songs of Experience" that are pervaded with an atmosphere of intense sorrow and sadness, especially for small children (e.g. "The Angel”, “Ah! Sun-flower", "The Human Abstract", "Infant Sorrow", The School Boy"). Many of the poems in the "The Songs of Innocence" (1789) are rewritten or revised in the "Songs of Experience", with the result that joyful atmosphere or the harmonious ending is in each case changed into a bitter mood or a sad story. The most outstanding poem in "The Songs of Experience" (1794) is the poem "London" in which Blake utters his social criticism. It shows the miseries of the common people. The poems in "The Songs of Experience" (1794) have attained to strange height of lyrical beauty, because in form these songs hearken back to the great lyrics of the Renaissance era, but the very somberness of their themes, with the curious mixture of social criticism and otherworldly mysticism, gives these poems high seriousness that stands in sharp contrast with the light-hearted fun of 16th-century lyrics.

Many poems in the two collections contradict each other. They have the same title in the two books, but are opposite in meanings. The contrast is of great significance. It marks a progress in the poet's outlook on life. For example, in both collections there're poems entitled The Chimney Sweeper, but the tone and atmosphere are entirely different.

\section{Features of William Blake's poems}

Blake employs plain and direct language to writes his poems. We can always find the beauty of the lyric and the profound meaning of his poems. He doesn't like and doesn't believe in the abstract things, so he is fond of showing his views with vivid visual images. Another distinctive feature in his poem is the wildly used symbolism. Blake should be remembered chiefly for his "Songs of experience" in which he poured out his bitter social criticism on the reality of his day, but also for the topical references to the fight for the freedom and the expose of tyranny in "The French Revolution" and "America" and "The Songs of Los", and for the great lyricism with which these poems and these great pages are written. The most extraordinary literary genius of his age. His lyrics display all the characteristics of the 
romantic spirit (natural sentiment \& individual originality). He influenced the Romantic poets with recurring themes of good and evil, heaven and hell, knowledge and innocence, and external reality versus inner imagination. Blake was opposed to the classicism of the 18th century. His poems were full of romantic spirit, imagery symbolism and revolutionary spirit. A Pre-Romanticist or forerunner of romantic poetry of the 19th century.

\section{AN ANALYSis OF William BlaKE’S “LONDON”}

As is mentioned above, "London" is the most outstanding poem in "The Songs of Experience". In this poem, William Blake utters his social criticism. It shows the miseries of the common people.

I wandered thro each chartered street,

Near where the charted Thames does flow,

And mark in every face I meet

Marks of weakness, marks of woe

In every cry of every man,

In every infant's cry of fear,

In every choice, in every ban,

The mind-forged manacles I hear.

How the chimney-sweeper's cry

Every blackening church appals;

And the hapless soldier's sigh

Runs in blood down palace walls.

But most through midnight streets I hear

How the youthful harlot's curse

Blasts the new-born infant's tear,

And blights with plagues the marriage hearse.

(http://wenku.baidu.com/view/ba3b3bd026fff705cc170a1f.html May, 2013)

\section{A. An Introduction to the Poem}

Often referred to as a social commentator, a large number of Blake's poems focused on similar themes that were relevant to the society in which he was writing, such as poems on industrialization, child labor and the more general notions of man versus nature and the individual against society, etc. "London" is no exception to this, acting as a social commentary on Blake's time. At first, Blake loved London, he wrote that "golden London and her silver Thames, throng'd with shining spires and corded ships"(Poetical Sketches), but after French Revolution, the British government began to oppress the civil democratic activities. Then London was quite different from before: everything was covered with darkness, terrors and miseries.

In this poem, Blake draws from his personal observations and gives a comprehensive picture of the many miseries, physical and spiritual, in the English capital London. He paints a picture of the dirty, miserable streets of London and describes the wretched people at the bottom of the society: the chimney-sweepers, soldiers, and harlots. The entire poem centers on the wails of these people from their pain and the injustices done to them, and exposes the gap between those in power and the misery of poor people. The poem is representative of English economic problems of the time, condemning many powerful institutions such as the church, royalty, the new industries, and the military. The main subject and theme of this poem is man's lack of freedom and the causes of this lack. It is a relatively unique poem, in that it takes such a negative and critical view of London, when at the time the city represented the pinnacle of technology, and was considered the center of western culture and Brutish Empire.

\section{B. Technical Features in the Poem}

"London" is an outstanding poem not only due to the subject and theme reflected in it but also due to the almost flawless writing techniques used by the poet. The following are some of the technical features in this poem.

\section{Images.}

The key image in this poem is "the mind-forg'd manacles"- attitudes which take away our freedom of thought and action. Three powerful examples of those who are not free, or three encounters who have "weakness" and "woe" are the chimney-sweeper, the soldier and the harlot.

The "mind-forged manacles" of the second stanza is the key image and the central metaphor of this poem. Blake imagines the mind as a forge where "manacles" are made. Manacles and shackles for the legs, would be seen on convicts, perhaps passing along the streets on their way to prison or, commonly in London in Blake's time, on their way to ships, for transportation to Australia. For Blake and his readers, the image is very striking and horrible. The image is also an allusion to an even more famous statement. In 1762, some thirty years before Blake wrote "London", the Swiss philosopher Jean-Jacques Rousseau wrote in "The Social Contract", "Man is born free, but everywhere he is in chains". Blake agrees with Rousseau that man's lack of freedom, his "manacles" are "mind-forged"- they come from the ideas and outlook imposed on us by external authority. Mind forged manacles lie at the heart of the poem.

The examples of the "the mind-forg'd manacles" start with the chimney-sweeper. As the church building is literally 
"black'ning" with smoke from the chimneys, so the church as an organization, which should help the poor, is blackened, metaphorically, with shame at its failure to give that help. The church should be appalled by the cry of the "chimney-sweeper".

The second image is the "hapless" solider. The poem was written shortly after the start of the French Revolution: the uprising was so bloody that the figure of speech called hyperbole was often used, as blood was said to be running down the walls. Blake shows how the unhappiness of the English soldier could, if its causes were ignored, lead to similar bloodshed here.

The last image - the harlot, is the most shocking to Blake as well as to us. The harlot is the truth behind respectable ideas of marriage. New birth is not a happy event but only to continue the cycle of misery, and the wedding carriage is seen as a hearse, leading to a kind of death. The word "plagues" here suggests the sexually transmitted diseases, which the "youthful harlot" would contract, and pass on to others, giving her cursing words real destructive power.

\section{Capitalization}

Capitalization is used extensively throughout the poem, to infer something beyond the simple meaning of the word - it usually means something deeper. For instance, the capitalization of Man in the second stanza suggests that the whole of urbanized society has gone to the state of moral decay and misery. "every Infants cry"- the capital letter shows that there is something beyond just children that the persona meets-also innocence, which is being corrupted by fear; instead of child idealistically being given security or a haven, here they have to fear and be afraid. Capitalization is also used in "Chimney-sweeper's cry", "Church", "Soldier", "Palace", "Harlot", and "Marriage"- usually to represent an idea beyond just the word, or an institution which will be criticized. For instance, "Soldier" represents the army, "Chimney-sweeper" represents child labor, "Harlot" represents prostitution, "Palace" symbolizes royal family, etc. Capitalization is used a lot, and represents the institutions, and is accompanied by the reason why Blake is criticizing these institutions.

\section{Choice of words}

The careful choice of some words also enhanced the theme of this poem. The following are some examples.

The use of the word "charter'd" in the first line is rich in imagery. It introduces imagery of mankind in bondage - showing that oppression, not freedom or individuality is the condition of the London that Blake writes about. "Charter'd" also means hired out, or leased, and shows that the city is in the hands of the merchants, and even the streets and the river Thames is being controlled for profits.

The use of "face" in the first stanza dehumanizes the words - the persona is not seeing marks of weakness or woe in a human person, just a blank face. The poet chooses the word "face" instead of "person" to show the loss and sorrow of the people.

"Blackening" is an easy and common word, but in this poem, the poet wonderfully chooses this word which literally means blackening with smoke, but metaphorically means blackening with shame at its failure to give that help. At the same time, this word contrasts with "appalls" which means makes pale. Such a simple word conveys so much information, so we have to admire the poet's technique in choosing words.

"Harlot" is a Biblical word, and is stronger than "prostitute". By using this word, the poet expresses his deep worry and strong condemnation of the society. And thus, the last stanza is the most powerful part of the poem. The unfortunate women are forced to be harlots. Just according to their curses, we can see everything covered with darkness, so the wedding becomes a funeral. Here "marriage hearse" is an apparent contradiction and is a figure of speech known as an oxymoron. It is used satirically to compare the wedding to a funeral and foretells what kind of future England must be faced with if things go like this.

\section{Repetitions}

In this poem, Blake uses many powerful devices to enhance the expression of the theme, one of which is the use of repetition for special purposes.

In the first stanza, there is something awkward in the repetition of the word "mark". The first "mark" is a verb, the second and last are nouns. So there were two complex effects: The observer "marks", but he marks "marks". Blake reinforces the effect of being dragged into an imprisoned world, where nothing reveals from the faces he meets, but weakness and woe. In the second stanza, the poet even uses "every" for five times, showing that no one can escape from the miserable and tragic reality, that is, there are "The mind-forg'd manacles" everywhere. The repetition of "cry", "cry of every man", "Infant's cry of fear", "the Chimney-sweeper's cry" and even "the hapless Soldier's sigh", emphasize how the people in London suffered at that time.

\section{Rhyme and rhythm}

This poem is famous for highly strong musical pattern. Generally speaking, the rhyme and rhythm is very definite and structured - the rhyme is $\mathrm{ABAB} C \mathrm{CDCD}$, and this poem is written with a metrical pattern of iambic tetrameter sporadically blended with trochaic tetrameter-which can help to accentuate the line, with 7 syllables and the first word stressed. The changes are acquired by the special purposes, i.e. the emphasis of the meaning. The alteration of the stresses on the syllables in each line makes the poem sound like striking of the anvil, and also helps the poem to be more powerful. So one of the most striking characteristics of this poem is the anvil music.

In addition to the technical features mentioned above, "London" begins with the verb set in the present tense. This 
implies that the poem concerns timeless realities unbounded by references to any particular incident. The use of a persona in this poem who clearly has firsthand knowledge of London's conditions lends credibility to the poem, making it more personal and emotive.

\section{CONCLUSION}

William Blake was the most extraordinary literary genius of his age. His lyrics display all the characteristics of the romantic spirit. He influenced the Romantic poets with recurring themes of good and evil, heaven and hell, knowledge and innocence, and external reality versus inner imagination. His poems were full of romantic spirit, imagery symbolism and revolutionary spirit. He was the forerunner of romantic poetry of the 19th century.

As for his poem "London", as is all shown above, with the vivid images and the various techniques, Blake shows us the great suffering of the British society during the French Revolution and Industrial Revolution, so that "London" deserves "the mightiest brief poem". Overall "London" is a very pessimistic poem that expresses no solutions to the issues mentioned within each line. By its conclusion, this nightmarish impression of darkness is heavily imbued within the thoughts of the reader. Perhaps just as William Blake would have intended, this poem is to truly convey the horror and injustice that was London.

\section{REFERENCES}

[1] William Blake. (2010). Songs of Experience. Montana USA: Kessinger Publishing.

[2] Northrop Frye. (2004). Northrop Frye's Notebooks on Romance, Toronto: University of Toronto Press; 2nd revised edition.

[3] Nick Rawlinson. (2003). William Blake's Comic Vision, New York: St. Martin's Press.

[4] Jean-Jacques Rousseau. (1968). The Social Contract,UK: Penguin Books Limited.

[5] Zongshe Zheng. (1995). Excellent Academic papers in China, Chengdu: Chengdu University of Science and Technology Press.

[6] Weiren Wu. (1988). History and Anthology of English Literature, Beijing: Foreign Language Teaching and Research Press.

[7] http://en.wikipedia.org/wiki/William_Blake, May, 2013.

[8] http://wenku.baidu.com/view/ba3b3bd026fff705cc170a1f.html May, 2013.

Changjuan Zhan was born in Longkou, China in 1963. She received her Bachelor's degree of English Education in Shandong Normal University in 1985.

She is currently an associate professor in the college of foreign languages, Qingdao University of Science and Technology, Qingdao, China. Her research interests include applied linguistics and English language teaching. 